\title{
Decision Support System for Alternative Selection of Family Medicinal Plants using the WEB-Based TOPSIS Method
}

\author{
Nurasima Wahid \\ Software Engineering Technology, \\ Agriculture Polytechnic of \\ Samarinda, Samarinda, 75242, \\ Indonesia \\ nrasima.wahid@gmail.com
}

\author{
Dwi Arief Prambudi \\ Information System, \\ Kalimantan Institute of Technology, \\ Balikpapan, 76127, \\ Indonesia \\ prambudiariefdwi@gmail.com
}

\author{
Nurlaila \\ Software Engineering Technology, \\ Agriculture Polytechnic of \\ Samarinda, Samarinda, 75242, \\ Indonesia \\ bintang_saddam@yahoo.co.id
}

\begin{abstract}
Indonesia is a growing place for 80 percent of medicinal plants in the world with 28,000 plant species are grown and 1,000 species of which have been used as medicinal plants. The utilization of plant raw materials is still fixed by one type of material even though these materials can be used by various types of diseases. Family Medicinal Plants, known as "TOGA", are cultivated plants that have natural medicinal properties and can cure minor ailments that often occur in families, and now can be cultivated in the yard. The TOPSIS method was chosen because it makes it easier for users to determine alternative types of family medicinal plants or traditional medicines in the surrounding environment, called a decision support system. This research was conducted at Sari Bumi Farmer Group, Sambiloto Street RT 14 No. 24. The research period was \pm 6 (six) months, from October 2018 - March 2019 which included making proposals, collecting data, making applications, and compiling reports. The "TOGA" Selection Decision Support System using the TOPSIS Method makes it easy for users to choose plants that can be used as medicine and to determine the type of medicinal plant family based on different criteria for each existing plant.
\end{abstract}

Keywords-Family Medicinal Plants, Decision Support System, TOPSIS Method.

\section{INTRODUCTION}

Indonesia is a very large archipelago country. As a tropical country, Indonesia has extensive tropical forests. Indonesia's tropical forests have a high level of biodiversity. Hidayat (2006) in Fahrurozi (2014) said, "Indonesia is very rich in various types of plants, namely there are approximately 30 thousand types of 40 thousand types of plants in the world. About $26 \%$ has been cultivated and the remaining $74 \%$ is still growing wild in the forest". According to Pramono (2002) "Indonesia's tropical forests are estimated to reach 143 million ha, which is where 80 percent of the world's medicinal plants grow, where 28,000 plant species are grown and 1,000 species of which have been used as medicinal plants".
Family Medicinal Plants or known as TOGA has been widely recognized by the public. The use of TOGA as an alternative medicine by the Indonesian people is not new. However, in selecting raw materials for TOGA, sometimes we still lack information. Limited information makes TOGA users only fixated on one type of material.

TOGA raw materials are not only effective in one type of disease but can also be efficacious in various types of minor ailments in the family caused by bacteria, viruses or parasites in certain media. Mild diseases in the family include upper respiratory tract infections (ISPA), hypertension, gout, diabetes, ulcers, lumbago, vaginal discharge and menstrual pain.

Based on the description above, it is necessary to conduct research with the title "Decision Support System for Selection of Alternative Types of Family Medicinal Plants with the WEB-based TOPSIS Method" with the hope of making it easier for users to determine alternative types of family medicinal plants or traditional medicines in our environment by considering 5 criteria that can be used as a reference for choosing TOGA. This system is commonly referred to as a decision support system. This decision support system will be based on a method, namely the Technique for Order Preference by Similarity to Ideal Solution (TOPSIS) method, this method uses the principle that the chosen alternative not only has the shortest distance from the positive ideal solution, but also has the longest ideal distance from the distance. negative ideal.

In the decision support system for selecting the TOGA plant species, there are criteria that are used as a reference, namely efficacy, price, taste, part consumed and processing methods so that they can produce an appropriate decision recommendation. The alternatives offered when people have difficulty getting the "TOGA" they want are very diverse. Like when people need ginger for cough medicine, but at that time it is not ginger season, or at that time the price of ginger is very expensive, this problem can be solved by replacing it with lime which has the same properties to cure coughs. The problem that often arises is the selection of the same ingredients or properties. 
Based on the background above, the problem formulation is as follows:

1. How to design and build a decision support system application for alternative selection of family medicinal plants using the WEB-based TOPSIS method?

2. How to determine the alternative types of family medicinal plants (TOGA) with the TOPSIS method?

Given the above problem is too broad, in this study the researcher will limit the problem to be studied. The problem limitations of this study are as follows:

1. The types of plants used as research materials are types of TOGA such as betel leaf, red ginger, sambiloto, cat's whiskers, turmeric, temugiring, lime.

2. The types of diseases that will be discussed are the types of minor illnesses in the family such as flu, cough, fever, asthma, tonsils, pharyngitis, ulcers, diarrhea, gout, menstrual pain, lumbago, vaginal discharge, and aching rheumatism.

3. Priority criteria in selecting medicinal plants are properties, price, taste, part of the plant consumed, and processing methods.

The research objectives and expected results from the above formulation are as follows:

1. Designing a computer-based decision support system for selecting alternative types of medicinal plants in the family against minor ailments.

2. Implementing the TOPSIS method as a decision support medium for the choice of alternative types of family medicinal plants using criteria, namely efficacy, price, taste, part consumed and processing methods.

3. Helping to facilitate the community as users in determining alternative types of family medicinal plants to be used.

\section{LITERATURE REVIEW}

\section{A. Scientific Study}

Some of the literature as a guide and reference in this Final Project include :

a) Research conducted by Bangkit, Regasari and Firdaus (2014) with the title Decision Support System for the Selection of Athletes Eligible to Enter the Pencak Silat Team with the SAW Method. This system aims to facilitate the selection of pencak silat athletes.

b) The research was conducted by Kurniasih (2013) with the title Laptop Selection Decision Support System with the TOPSIS Method. This system aims to help determine the choice of a laptop that suits your wishes and budget.

c) The research was conducted by Kamaludin (2012) with the title Decision Support System in the Selection of Alternative Contraceptives with the SAW Method. This system aims to provide convenience in obtaining information about the advantages and disadvantages of contraceptives by using PHP as the programming language and MySQL as the database server and Apache as the WEB server. d) The research was conducted by Guntur and Widodo (2013) with the title of the Scholarship Support System for New Students using the TOPSIS Method. This system aims to provide a correct, effective and efficient decision in managing the data of scholarship recipients who are truly entitled to receive scholarships using the PHP programming language and database design using MySQL.

e) Research conducted by Mallu (2015) entitled Decision Support System for Determining Contract Employees to become Permanent Employees using the TOPSIS Method. This system aims to assist companies in selecting the right employees using the Java NetBeans and XAMPP programming languages.

The difference in research conducted with previous researchers is to use the Decision Support System for the Alternative Selection of Family Medicinal Plants with the TOPSIS method, the system is built using the PHP programming languages and XAMPP.

\section{B. Decision Support System.}

Decision Support System (DSS) is a system that is able to provide problem solving and communication capabilities for problems with semi-structured and unstructured conditions. This system is used to assist decision making in semi-structured and unstructured situations, where no one knows exactly how decisions should be made (Turban, 2001).

\section{Technique for Order Preference by Similarity to Ideal Solution (TOPSIS)}

Technique for Order Preference by Similarity to Ideal Solution (TOPSIS) is a multi-criteria decision-making method that was first introduced by Yoon and Hwang (1981). TOPSIS uses the principle that the chosen alternative is the best alternative that has the shortest distance from the positive ideal solution and the farthest distance from the negative ideal solution (Cheng, 2000).

The steps taken in solving a problem using the TOPSIS method are as follows:

a) Creating a normalized decision matrix, with (1)

$$
r_{i f}=\frac{x_{i f}}{\sqrt{\sum_{i=1}^{m} x_{i j}^{2}}}
$$

b) Create a weighted, weighted normalized decision matrix (2)

$$
y_{i f}=w_{i} r_{i f}
$$

c) Determine the ideal solution matrix for positive and negative solutions (3)(4)

$$
\begin{aligned}
& \mathrm{A}+=() ; y_{1}^{+}, y_{2}^{+}, \ldots \ldots y_{n}^{+} \\
& \mathrm{A}-=() ; y_{1}, y_{2}^{-}, \ldots \ldots y_{n}^{-}
\end{aligned}
$$

d) Determine the distance between the value of each alternative with the positive and negative ideal solution matrix (5) (6) 


$$
\begin{aligned}
& D_{i}^{+}=\sqrt{\sum_{j=1}^{n}\left(y_{i j}-y_{i}^{+}\right)^{2} ; i=1,2, \ldots, m} \\
& D_{i}^{-}=\sqrt{\sum_{j=1}^{n}\left(y_{i f}-y_{i}^{-}\right)^{2}{ }_{;} i=1,2, \ldots, m}
\end{aligned}
$$

e) Specifies the preference value for each alternative. The relative proximity of the alternative $\mathrm{A}+$ to the ideal solution A- is represented by the (7)

$$
c_{i}=\frac{S_{i}^{-}}{S_{i}^{-}+S_{i}^{+}}
$$

\section{Family Medicinal Plants}

TOGA is a plant that has medicinal properties. TOGA is basically a plot of land, either in the yard, garden or field that is used to cultivate medicinal plants in order to meet the family's needs for medicine. Garden of medicinal plants or medicinal substances which can then be distributed to the public, especially medicines derived from plants. Cultivating TOGA can spur small and medium enterprises in the field of herbal medicines even if done individually. Each family can cultivate medicinal plants independently and use them, so that the principle of independence in family medicine will be realized (From Wikipedia in Indonesian, the free encyclopedia).

Table 1. Family Mechanical Plant (TOGA)

\begin{tabular}{|c|l|l|}
\hline No. & \multicolumn{1}{|c|}{ Plant Name } & \multicolumn{1}{c|}{ Latin name } \\
\hline 1 & Betel leaf & Piper betle L \\
\hline 2 & Red ginger & Zingiber officinale \\
\hline 3 & Sambiloto & Andrographis paniculata \\
\hline 4 & Cat whiskers & Orthosiphon aristatus \\
\hline 5 & Turmeric & Curcuma longa \\
\hline 6 & Temugiring & Curcuma heyneana \\
\hline 7 & Lime & Citrus aurantiifolia \\
\hline
\end{tabular}

\section{RESEARCH METHODS}

The following describes the research object, methods and stages of the research conducted;

\section{A. Research Method}

The method used in making decision support system applications for alternative selection of family medicinal plants is the waterfall method. This method is a method often used by system analyzers in general. The essence of the waterfall method is that the work of a system is carried out sequentially or linearly. So, if step one has not been done then you will not be able to carry out steps 2, 3 and so on. Automatically the 3rd stage will be carried out if the 1st and 2nd stages have been done. This system modeling is very suitable for the quality of the system which is maintained due to its structured development. Broadly speaking, the waterfall method according to Sudarman (2007) has the following steps: Analysis, System Design, Code Writing, Testing, and Implementation.

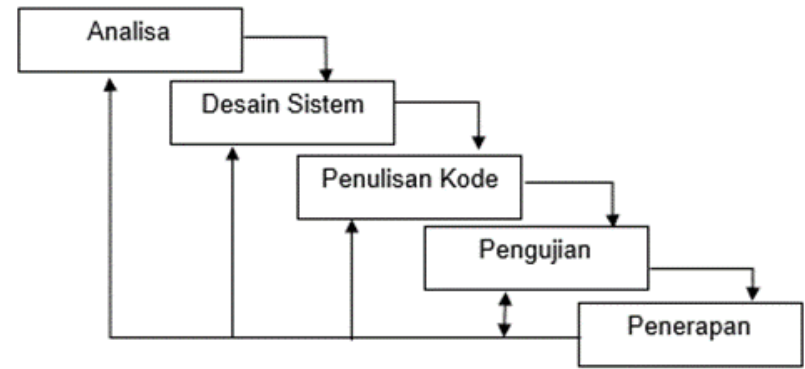

Figure 1. Waterfall Method

\section{B. Research Procedure}

Research is a process that is systematically structured to be carried out based on existing scientific methods. (Emzir, 2012) and According to Muhammad Ali (2000) "Procedure is a work procedure or how to carry out a job".

So, we can conclude that a general research procedure is a series, arrangement, procedure or process that is generally used in conducting a research.

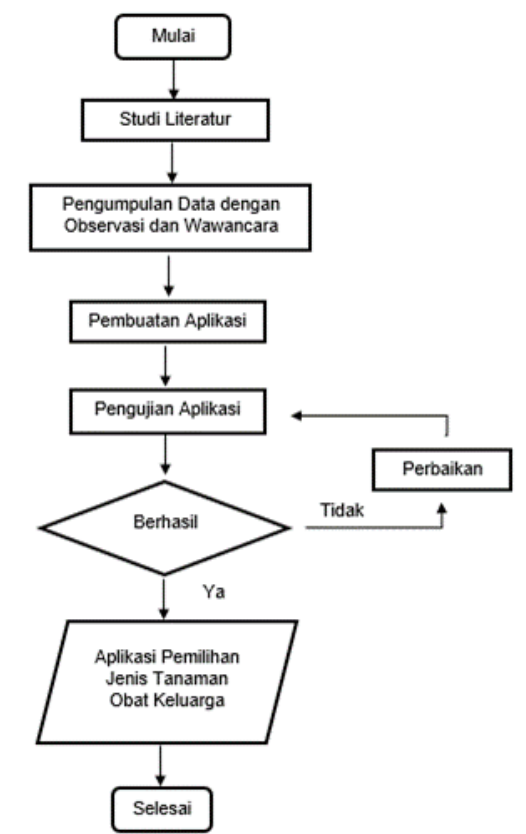

Figure 2. Diagram of Research Procedures

\section{Requirement Criteria}

The following are the specified criteria, namely Efficacy (K1) Price (K2) Taste (K3) Consumed portion (K4) Processing Method (K5).

Table 2. Criteria

\begin{tabular}{clc}
\hline Code & \multicolumn{1}{c}{ Name Criteria } & $\begin{array}{c}\text { Weight } \\
\text { Value }\end{array}$ \\
\hline K1 & Efficacy (benefit attribute) & 35 \\
K2 & Price (cost attribute / cost) & 25 \\
K3 & Taste (benefit attribute) & 20 \\
K4 & Share that is consumed (benefit attribute) & 15 \\
K5 & Processing Method (cost attribute / cost) & 10
\end{tabular}

As for the grading of each sub-criteria as in the following table 3 . 
Table 3. Sub-Criteria

\begin{tabular}{|c|c|c|c|}
\hline Code & Criteria & Sub-criteria & Score \\
\hline \multirow{5}{*}{ K1 } & \multirow{3}{*}{ Efficacy } & Ineffective & 25 \\
\hline & & $\begin{array}{l}\text { Effective } \\
\text { enough }\end{array}$ & 50 \\
\hline & & Effective & 75 \\
\hline & & Very effective & 100 \\
\hline & & Very expensive & 25 \\
\hline \multirow{4}{*}{ K2 } & Price & Expensive & 50 \\
\hline & & Cheap enough & 75 \\
\hline & & Cheap & 100 \\
\hline & & Bitter & 25 \\
\hline \multirow[t]{5}{*}{ K3 } & Taste & Acid & 50 \\
\hline & & Sweet & 75 \\
\hline & & It is tasteless & 100 \\
\hline & & Root & 25 \\
\hline & The consumed portion & Trunk & 50 \\
\hline \multirow[t]{3}{*}{ K4 } & & Flower leaf & 75 \\
\hline & & Fruit / Rhizome & 100 \\
\hline & & Not easy & 25 \\
\hline \multirow[t]{3}{*}{ K5 } & Processing Method & Quite easy & 50 \\
\hline & & Easy & 75 \\
\hline & & Very easy & 100 \\
\hline
\end{tabular}

The value description with the case to be tested is to treat cough disease.

Table 4. Translation of Value

\begin{tabular}{|l|l|l|l|l|}
\hline Criteria & Betel leaf & $\begin{array}{l}\text { Cat } \\
\text { whiskers }\end{array}$ & Temugiring & Lime \\
\hline K1 & 100 & 75 & 100 & 50 \\
\hline K2 & 100 & 50 & 50 & 75 \\
\hline K3 & 100 & 100 & 100 & 100 \\
\hline K4 & 75 & 25 & 100 & 100 \\
\hline K5 & 100 & 75 & 50 & 50 \\
\hline
\end{tabular}

The first step:

$$
\begin{aligned}
\boldsymbol{x} \mathbf{1} & =\sqrt{\mathbf{1 0 0}^{2}+\mathbf{7 5}^{\mathbf{2}}}+\mathbf{1 0 0}^{\mathbf{2}}+\mathbf{5 0}^{2}=\mathbf{1 6 7 , 7 0} \\
R 1 & =\frac{100}{167,70}=0,59 \\
R 2 & =\frac{75}{167,70}=0,44 \\
R 3 & =\frac{100}{167,70}=0,59 \\
R 4 & =\frac{50}{167,70}=0,29 \\
R & =\left\{\begin{array}{lllll}
0,59 & 0,69 & 0,50 & 0,46 & 0,69 \\
0,44 & 0,34 & 0,50 & 0,15 & 0,52 \\
0,59 & 0,34 & 0,50 & 0,61 & 0,41 \\
0,29 & 0,52 & 0,50 & 0,61 & 0,20
\end{array}\right]
\end{aligned}
$$

Second step:

$$
Y=\left\{\begin{array}{lllll}
20,65 & 17,25 & 10,00 & 6,90 & 6,90 \\
15,40 & 8,50 & 10,00 & 2,25 & 5,20 \\
20,65 & 7,80 & 10,00 & 9,15 & 4,10 \\
10,15 & 13,00 & 10,00 & 9,15 & 2,00
\end{array}\right\}
$$

Third step:

Solusi Ideal Positif $\left(\mathrm{A}^{+}\right)$

$\begin{array}{ll}Y 1=\operatorname{Max}(20,65 ; 15,40 ; 20,65 ; 10,15) & =20,65 \\ Y 2=\operatorname{Min}(17,25 ; 8,50 ; 7,80 ; 13,00) & =7,80 \\ Y 3=\operatorname{Max}(10,00 ; 10,00 ; 10,00 ; 10,00) & =10,00 \\ Y 4=\operatorname{Min}(6,90 ; 2,25 ; 9,15 ; 9,15) & =2,25 \\ Y 5=\operatorname{Max}(6,90 ; 5,20 ; 4,10 ; 2,00) & =6,90 \\ A^{+}=(20,65 ; 7,80 ; 10,00 ; 2,25 ; 6,90) & \\ \text { Solusi Ideal Negatif }\left(A^{-}\right) & \\ Y 1=\operatorname{Min}(20,65 ; 15,40 ; 20,65 ; 10,15) & =10,15 \\ Y 2=\operatorname{Max}(17,25 ; 8,50 ; 7,80 ; 13,00) & =17,25 \\ \text { Y3 }=\operatorname{Min}(10,00 ; 10,00 ; 10,00 ; 10,00) & =10,00 \\ \text { Y4 }=\operatorname{Max}(6,90 ; 2,25 ; 9,15 ; 9,15) & =9,15 \\ \text { Y5 }=\operatorname{Min}(6,90 ; 5,20 ; 4,10 ; 2,00) & =2,00 \\ A^{-}=(10,15 ; 17,25 ; 10,00 ; 9,15 ; 2,00) & \end{array}$

Fourth step:

Jarak Solusi Ideal Positif

$\mathrm{D} 1=\sqrt{(20,65-20,65)^{2}+(17,25-7,80)^{2}}+(10,00-10,00)^{2}+(6,90-$ $2,25)^{2}+(6,90-6,90)^{2}=\sqrt{110,92}=10,53$

$\mathrm{D} 2=\sqrt{(15,40-20,65)^{2}+(8,50-7,80)^{2}}+(10,00-10,00)^{2}+(2,25-$ $2,25)^{2}+(5,20-6,90)^{2}=\sqrt{30,94}=5,56$

$\mathrm{D} 3=\sqrt{(20,65-20,65)^{2}+(7,80-7,80)^{2}}+(10,00-10,00)^{2}+(9,15-$ $2,25)^{2}+(4,10-6,90)^{2}=\sqrt{55,45}=7,44$

$\mathrm{D} 4=\sqrt{(10,15-20,65)^{2}+(13,00-7,80)^{2}}+(10,00-10,00)^{2}+(9,15-$ $2,25)^{2}+(2,00-6,90)^{2}=\sqrt{208,91}=14,45$

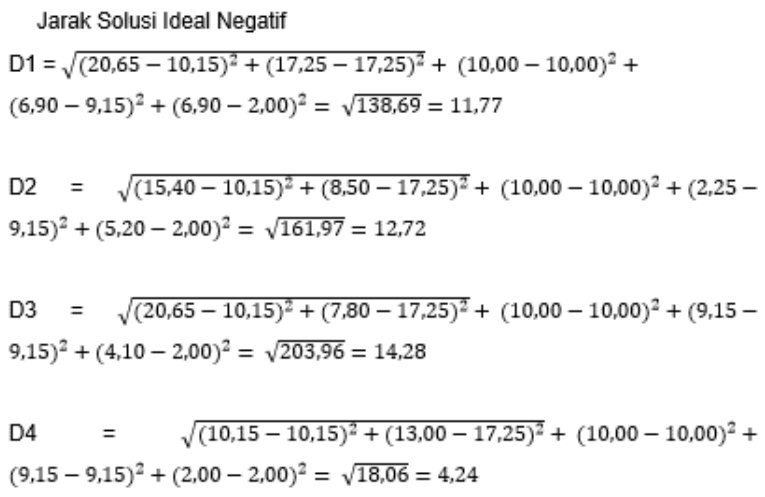

Fifth step:

$$
\begin{aligned}
& V 1=\frac{11,77}{11,77+10,53}=0,52 \\
& V 2=\frac{12,72}{12,72+5,56}=0,69 \\
& V 3=\frac{14,28}{14,28+7,44}=0,65 \\
& V 4=\frac{4,24}{4,24+14,45}=0,22
\end{aligned}
$$

From the results of the manual calculation above, it is concluded that V2's Whisker Cat is the maximum value where the alternative will be chosen. 


\section{RESULTS AND DISCUSSION}

\section{A. Result}

The implementation stage is the coding stage of the design that has been made into a programming language. The coding will produce an interface or display of the Alternative Selection Decision Support System for Family Medicinal Plants using the WEB-based TOPSIS method

a) Main Page

The main page is a menu that contains the main features in this system. On this page contains menus including Home, Master, Assessment, Analysis, Calculation and Exit.

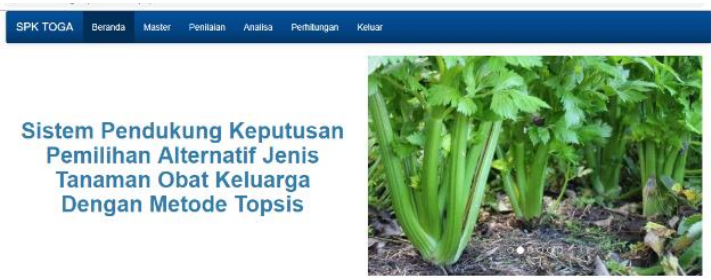

b) Login Page

Figure 3. Main Page

The login page is used by admins and users to enter the system. In the image admin and user must enter the username and password that has been determined previously.

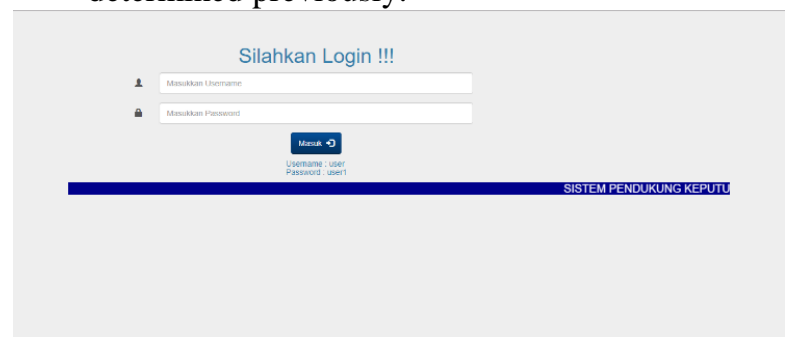

c) Criteria Data Page

Figure 4. Login Page

Criteria data are used to determine the weight of each criterion. Criteria data can be accessed by admin only.

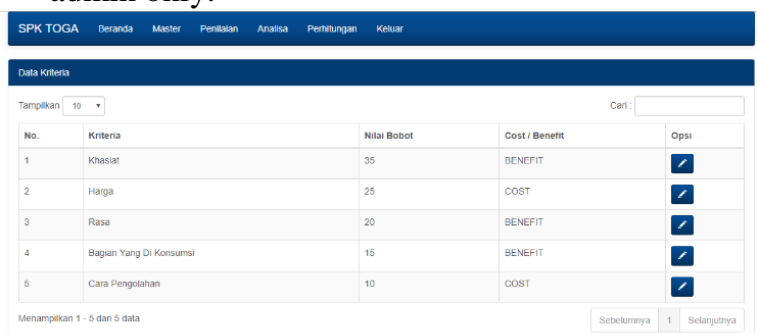

Figure 5. Criteria Data Page

\section{d) Crop Data Page}

Plant / Alternative Data is a page that is used as an alternative. This menu can be accessed by admin and user. The number of alternatives can be changed, added and deleted.

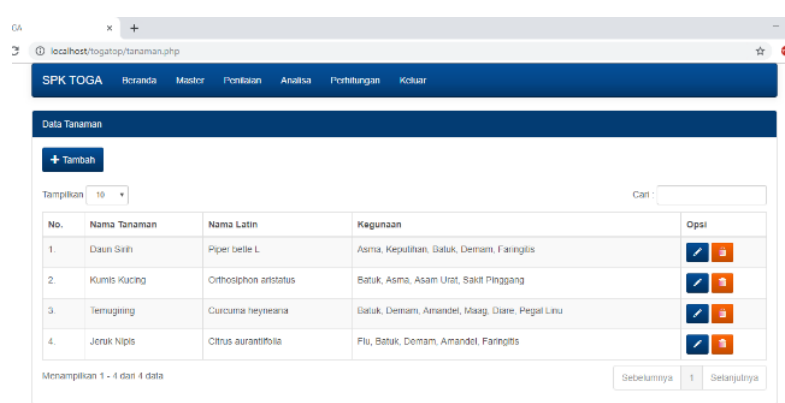

e) Rating Page

Figure 6. Crop Data Page

The Rating page is a page that is used to enter the criteria values for each offered alternative. This menu can be accessed by admin and user which is then used as material for TOPSIS calculations.

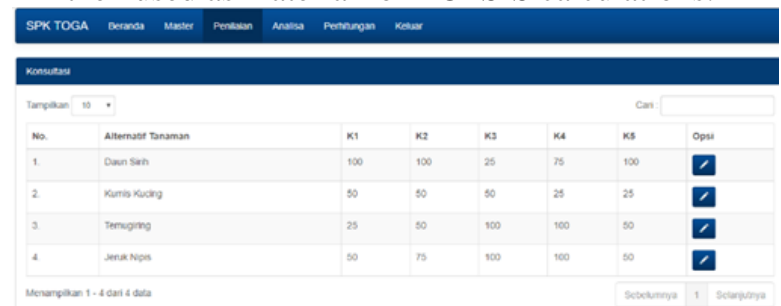

Figure 7. Assessment Page

f) Analysis Page

This display will show a graph and the analysis results of the assessment. This menu can be accessed / viewed by admin and user.

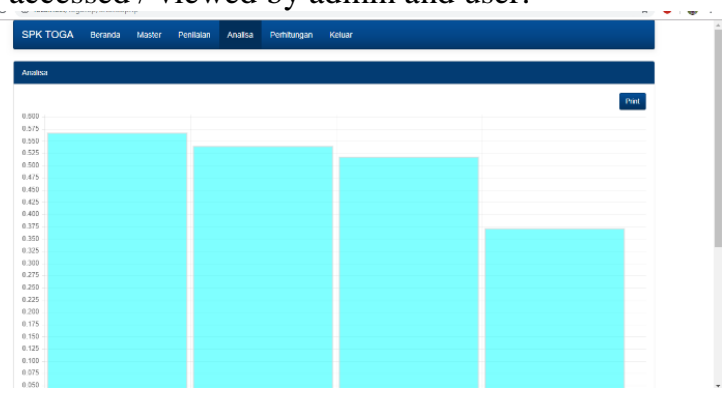

Figure 8. Analysis Page

g) Calculation Page

After the analysis page, the user can also see the TOPSIS calculation results in the system.

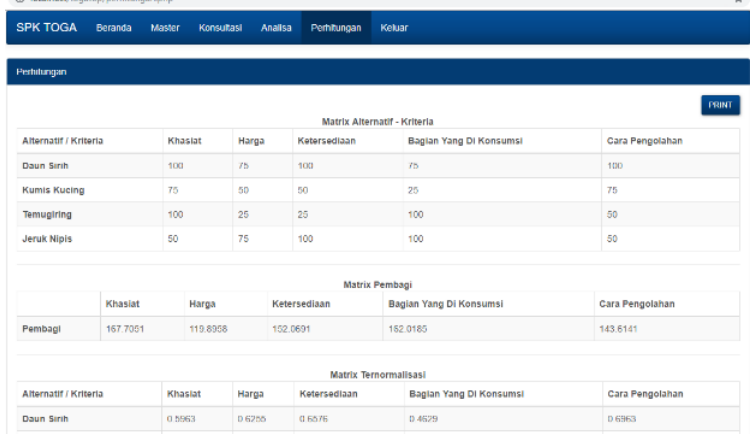

Figure 9. Calculation Page 


\section{B. Testing}

From the questionnaire testing that has been carried out, namely by testing the calculation of the choice of answer categories from the questionnaires that have been distributed in the field, it can be concluded that the Alternative Selection Decision Support System for Family Medicinal Plants has an attractive appearance, the system runs still according to its function, gives good results to users, user manuals help users in using the application, and are easy to use by users so that users do not have problems in making decisions. However, there are still shortcomings in this system, namely that it cannot add a combination of the main ingredients of medicinal plants with a mixture of other ingredients so that users know which mixture of TOGA ingredients is more effective.

Table 4. Manual Calculation using Excel

\begin{tabular}{|l|l|}
\hline Alternative & Score \\
\hline Betel leaf & 0.5418 \\
\hline Cat whiskers & 0.5375 \\
\hline Temugiring & 1 \\
\hline Lime & 0.4406 \\
\hline
\end{tabular}

The test results show that between manual calculations using Microsoft Excel in Table 4 and calculations on the system show in Figure 10, show the same calculation results. Applications can show plant assessments through rankings using TOPSIS.

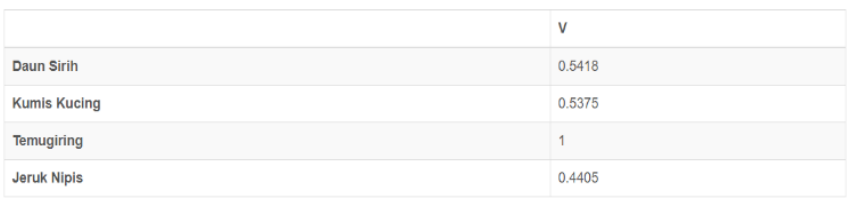

Figure 10. Calculation on system

\section{CONCLUSION}

Based on the results of the above research, the authors conclude that the TOGA Selection Decision Support System designed with the TOPSIS Method can make it easier for users to choose plants used as medicine and the Technique for Order Preference by Similarity to Ideal Solution (TOPSIS) method can be used to determine the type of family medicinal plants. based on manual calculations that have been done.

The suggestions in developing this application are that this system is only used for 5 criteria, 7 types of medicinal plants, 13 types of minor diseases. For further research, it can be further developed by adding criteria, types of medicinal plants and types of minor diseases. Applications need to be added information on the efficacy of TOGA and how to manufacture and further research can use other methods to determine alternative types of family medicinal plants.

\section{REFERENCES}

Brigida. (2013). Decision Making Process. Retrieved from informatika.WEB.id: http://informatika.WEB.id/proses-pengambilan kepUHAN.html

classification-and-characteristics-cat-whiskersmorphology-and-characteristics. (2015). Retrieved from http://www.materipertanian.com/klasifikasi-danciri-ciri-morfologi-kumis-kucing/

classification-and-characteristics-morphology-turmeric. (2015). Retrieved from https://www.materipertanian.com/klasifikasi-dan-ciriciri-morfologi-kunyit/

classification-and-characteristics-plant-to-be-girdle. (2015). Retrieved from https://www.materipertanian.com/klasifikasi-dan-ciriciri-tanaman-temu-giring/

classification-and-morphology-betel-leaf. (2015). Retrieved from http://www.materipertanian.com/klasifikasi-danmorfologi-daun-sirih/

classification-and-morphology-lime-lime. (2015). Retrieved http://www.materipertanian.com/klasifikasi-danmorfologi-jeruk-nipis/

classification-and-morphology-sambiloto. (2015). Retrieved from http://www.materipertanian.com/klasifikasi-danmorfologi-sambiloto/

Destiani, D., Ikhwana, A., \& Rustiawan, AH (2012). Decision Support System for Selection of New Student Candidates at SMA N 3 Garut using the TOPSIS method. Garut College of Technology Algorithm.

Kurniawan, F. (2019). classification-and-plantmorphology-ginger-red. Retrieved from http://fredikurniawan.com/klasifikasi-dan-morfologitanaman-jahe-merah/

Nugroho, AT, \& Rizki, V. (2011). TOPSIS Technique for Order Preference by Similarity to Ideal Solution. Retrieved from dss.konstructivelearning.info:http://dss.konstructivelearning.info/

Regasari, R., \& Mahmudy, WF (2014). Decision Support System for the Selection of Athletes Eligible for the Pencak Silat Team Using the Simple Additive Weighting (SAW) Method.

Riadi, M. (2013). decision-support-system-spk. Retrieved from www.kajianpustaka.com: https://www.kajianpustaka.com/2013/09/sistempendukung-kepUHAN-spk.html

Trinita, TS, \& Terriani, ST (t.y.). Decision Support System for TOGA Plant Selection Using Electre Method (Elimination Et Choix Tranduisant La Realite). Gresik: Qomaruddin Islamic College. 